\title{
Spatial Analysis of Prevalence of Early Marriage and HDI in Indonesia
}

\author{
Analisis Spasial Prevalensi Perkawinan Dini dan IPM di Indonesia
}

\author{
Afifah Jahra ${ }^{11 *}$, Fiqih Tri Mahendra ${ }^{2 *}$, Lathifah Dzakiyah $^{3^{*}}$, Salsavira $^{4 *}$
}

\begin{abstract}
Early marriage has become an important issue in Indonesia. Even though the rate of early marriage shows a decline until 2020, the number still makes Indonesia become the country with the second highest early marriage in Southeast Asia. Early marriage that occurs can hinder the achievement of the Sustainable Development Goals (SDG) and can have an impact on the Human Development Index. The existence of a relationship between early marriage and HDI encourages researchers to conduct studies that aimed at examining the effect of the prevalence of early marriage on HDI in each district/city in Indonesia on 2020. This study uses the Geographically Weighted Logistic Regression (GWLR) analysis method with the data sourced from the National Socio-Economic Survey (SUSENAS) raw data in March 2020 and publication data on the website of The Central Bureau of Statistics. The results of analysis found that the prevalence of early marriage has a negative and significant effect in several districts/cities in the Provinces of Aceh, North Sumatra, West Sumatra, Riau, Jambi, South Sumatra, Bengkulu, Lampung, Bangka Belitung Islands, Riau Islands, West Java, Central Sulawesi, South Sulawesi, Southeast Sulawesi, Maluku, and West Papua. This research is expected to be a recommendation for the government and community organizations to conduct socialization regarding the maturity age of marriage and the adverse effects that can be caused by early marriage.
\end{abstract}

Keywords: Early Marriage, Geographically Weighted Logistic Regression, Human Development Index

\begin{abstract}
Abstrak
Perkawinan dini telah menjadi permasalahan tersendiri bagi Indonesia. Meskipun angka perkawinan dini menunjukkan penurunan hingga tahun 2020, jumlahnya masih menjadikan Indonesia sebagai negara dengan perkawinan dini tertinggi kedua di Asia Tenggara. Perkawinan dini yang terjadi dapat menghambat tercapainya Sustainable Development Goals (SDG) dan dapat berdampak pada Indeks Pembangunan Manusia. Adanya hubungan antara perkawinan dini dan IPM, mendorong peneliti untuk melakukan studi yang bertujuan untuk mengkaji pengaruh prevalensi perkawinan dini terhadap IPM di setiap kabupaten/kota di Indonesia pada tahun 2020. Penelitian ini menggunakan metode analisis Geographically Weighted Logistic Regression (GWLR) dengan data yang bersumber dari raw data Survei Sosial Ekonomi Nasional (SUSENAS)
\end{abstract}

* Politeknik Statistika STIS

Email: jahrafifah@gmail.com ${ }^{1}$,fiqih.tm04@gmail.com², lathifahdzakiyah@gmail.com³, salsvir25@gmail.com ${ }^{4}$

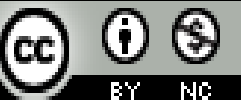

This work is licensed under a Creative Commons Attribution-NonCommercial 4.0 International License 


\section{Jumal Matematika, Statistika \& Komputasi Afifah Jahra, Fiqih Tri Mahendra, Lathifah Dzakiyah, Salsavira}

pada Maret 2020 dan data publikasi pada website Badan Pusat Statistik. Hasil analisis menemukan bahwa prevalensi perkawinan dini berpengaruh secara negatif dan signifikan di beberapa kabupaten/kota di Provinsi Aceh, Sumatera Utara, Sumatera Barat, Riau, Jambi, Sumatera Selatan, Bengkulu, Lampung, Kepulauan Bangka Belitung, Kepulauan Riau, Jawa Barat, Sulawesi Tengah, Sulawesi Selatan, Sulawesi Tenggara, Maluku, dan Papua Barat. Penelitian ini diharapkan dapat menjadi rekomendasi terhadap pemerintah bersama organisasi-organisasi masyarakat untuk melakukan sosialisasi mengenai pendewasaan usia perkawinan dan dampak buruk yang dapat diakibatkan oleh perkawinan dini.

Kata kunci: Geographically Weighted Logistic Regression, Indeks Pembangunan Manusia, Perkawinan Dini

\section{PENDAHULUAN}

SDGs atau Sustainable Development Goals merupakan agenda global yang dicanangkan oleh PBB untuk mewujudkan kesejahteraan dan perdamaian bagi seluruh masyarakat di dunia pada tahun 2030 [10]. SDGs terdiri dari 17 tujuan dan 169 target yang meliputi aspek sosial, ekonomi, dan lingkungan hidup. Prinsip dalam SDGs memastikan tidak ada seorangpun yang terlewatkan atau 'no-one left behind' dalam pembangunan berkelanjutan, termasuk dalam kesetaraan gender dan pemberdayaan perempuan yang tercantum dalam tujuan SDGs 5.3 yang berbunyi, "Menghapuskan semua praktik berbahaya, seperti perkawinan usia anak, perkawinan dini dan paksa, serta sunat perempuan".

Perkawinan dini telah menjadi permasalahan tersendiri bagi Indonesia. Meskipun data UNICEF Indonesia menunjukkan penurunan perkawinan dini yang berjalan lambat dari tahun ke tahun, namun jumlahnya masih menjadikan Indonesia sebagai negara dengan angka perkawinan dini tertinggi kedua di Asia Tenggara setelah Kamboja [9]. Sepanjang tahun 2019 hingga 2020 memang telah terjadi penurunan sebanyak $0,6 \%$, tetapi angka ini masih jauh dari target penurunan hingga 8,74\% pada 2024 [6]. Permasalahan perkawinan dini di Indonesia kemudian diperparah dengan adanya peningkatan perkawinan dini selama masa pandemi Covid-19. Kementerian PPPA mencatat hingga Juni 2020 angka perkawinan anak meningkat menjadi dua puluh empat ribu saat pandemi [8].

Deputi Tumbuh Kembang Anak Kementerian PPPA, Lenny N. Rosalin, menyatakan bahwa perkawinan dini dapat menghambat tercapainya Sustainable Development Goals (SDG) dan pada akhirnya akan berdampak pada Indeks Pembangunan Manusia yaitu dalam dimensi pengetahuan, umur panjang dan hidup sehat, dan standar hidup layak. Pada dimensi pengetahuan, angka perkawinan anak yang tinggi akan berpengaruh terhadap meningkatnya angka putus sekolah. Sedangkan pada dimensi umur panjang dan hidup sehat, perkawinan dini akan memberi dampak yang sangat berbahaya bagi ibu maupun anak. Usia ibu yang masih muda, ketika melahirkan akan memiliki resiko yang sangat besar untuk mengalami pendarahan sehingga dapat menyebabkan kematian bagi ibu maupun anak, hal tersebut tentu saja akan membuat angka harapan hidup menurun dan angka kematian ibu maupun bayi meningkat. Pada dimensi standar hidup layak, meningkatnya angka putus sekolah akan berakibat pada meningkatnya pekerja anak dan adanya upah rendah sehingga dapat menyebabkan kemiskinan yang berkelanjutan [6].

Selain alasan-alasan yang telah dipaparkan oleh Kementerian PPPA, beberapa penelitian terdahulu juga telah mengungkapkan adanya pengaruh perkawinan dini terhadap IPM [5][13]. Akan tetapi, tidak banyak penelitian-penelitian yang mengungkapkan efek spasial dan menggunakan unit analisis hingga level kabupaten/kota. Berdasarkan hal tersebut, peneliti akan mengkaji lebih lanjut mengenai pengaruh prevalensi perkawinan dini terhadap IPM di setiap kabupaten/kota di Indonesia pada tahun 2020. 


\section{Jumal Matematika, Statistika \& Komputasi Afifah Jahra, Fiqih Tri Mahendra, Lathifah Dzakiyah, Salsavira}

\section{METODE PENELITIAN}

\subsection{Teknik Pengumpulan Data}

Unit analisis pada penelitian ini berupa 514 kabupaten/kota di Indonesia. Studi ini menggunakan data sekunder yang bersumber dari Badan Pusat Statistik.

1) Data prevalensi perkawinan dini didapatkan dari raw data Survei Sosial Ekonomi Nasional (SUSENAS) pada Maret 2020.

2) Data IPM diperoleh dari tabel dinamis Indeks Pembangunan Manusia 2020 pada website Badan Pusat Statistik.

\subsection{Variabel Penelitian}

Variabel dependen dari penelitian ini adalah Indeks Pembangunan Manusia tahun 2020. Konsep pembangunan manusia diukur dengan menggunakan pendekatan tiga dimensi dasar manusia, yaitu umur panjang dan sehat, pengetahuan, dan standar hidup yang layak. Dimensi umur panjang dan sehat diwakili oleh indikator harapan hidup saat lahir. Dimensi pengetahuan diwakili oleh indikator harapan lama sekolah dan rata-rata lama sekolah, sedangkan dimensi standar hidup layak diwakili oleh pengeluaran per kapita. Dalam penelitian ini, IPM dikategorikan menjadi dua, yakni $\mathrm{Y}=0$ untuk IPM $<70$ atau IPM bernilai rendah dan $\mathrm{Y}=1$ untuk IPM $\geq 70$ atau IPM bernilai tinggi.

Variabel independen dari penelitian ini adalah prevalensi perkawinan dini. Penghitungan prevalensi perkawinan dini merupakan hasil bagi antara perempuan umur 20-24 tahun yang usia perkawinan pertamanya sebelum usia 18 tahun dengan seluruh perempuan usia 20-24 tahun. Perlu diketahui bahwa penghitungan ini mengacu pada metode penghitungan/indikator pada metadata Tujuan Pembangunan Berkelanjutan (TPB) dan telah sesuai dengan indikator nasional maupun global [2]. Metode kelompok usia lebih disukai karena meminimalkan pengaruh variasi di seluruh survei. Dengan menggunakan metode ini, tingkat perkawinan anak di kalangan wanita usia 20 hingga 24 tahun dapat dianggap sebagai estimasi terbaru, karena kelompok usia tersebut adalah kalangan usia yang paling akhir menyelesaikan paparan periode risiko [12]. Penggunaan batas umur 18 tahun mengadaptasi dari definisi perkawinan anak menurut United Nations Children's Fund (UNICEF) dan Badan Pusat Statistik (BPS), dimana UNICEF [11] menyatakan bahwa perkawinan dini adalah perkawinan yang dilaksanakan secara resmi atau tidak resmi yang dilakukan sebelum usia 18 tahun, dan BPS [2] mendefinisikan perkawinan dini sebagai perkawinan yang dilakukan melalui hukum perdata, agama atau adat, dan dengan atau tanpa pencatatan atau persetujuan resmi di mana salah satu atau kedua pasangan adalah anak di bawah usia 18 tahun. Hal tersebut juga mengacu kepada UU Nomor 35 tahun 2014 tentang perlindungan anak yang menyatakan bahwa definisi anak adalah seseorang yang belum berusia 18 tahun.

\subsection{Metode Analisis}

Analisis data yang digunakan dalam penelitian ini adalah analisis deskriptif dan analisis inferensia.

1) Analisis deskriptif dilakukan untuk mengetahui gambaran umum prevalensi perkawinan dini dan IPM di setiap kabupaten/kota di Indonesia pada tahun 2020. Analisis deskriptif menggunakan peta tematik yang diolah dengan bantuan software QGIS3.

2) Analisis inferensia dilakukan untuk mengidentifikasi pengaruh prevalensi perkawinan dini terhadap IPM di setiap kabupaten/kota di Indonesia pada tahun 2020. Analisis inferensia yang digunakan adalah Geographically Weighted Logistic Regression (GWLR) yang diolah dengan bantuan software Geoda dan GWR4. 


\section{Jurnal Matematika, Statistika \& Komputasi \\ Afifah Jahra, Fiqih Tri Mahendra, Lathifah Dzakiyah, Salsavira}

Langkah-langkah analisis inferensia yang dilakukan secara lebih lengkap adalah sebagai berikut:

1) Pemodelan dengan regresi logistik biner

Regresi logistik merupakan metode yang digunakan saat variabel dependen yang digunakan bersifat dikotomus atau polikotomus. Pada penelitian ini, variabel IPM sebagai variabel dependen dikelompokkan menjadi dua yakni $\mathrm{Y}=0$ untuk IPM $<70$ atau IPM bernilai rendah dan $Y=1$ untuk IPM $\geq 70$ atau IPM bernilai tinggi. Adapun rumus yang digunakan berdistribusi Bernoulli dengan distribusi peluang sebagai berikut [14]:

$$
\pi\left(x_{i}\right)=\frac{\exp \left(\beta_{0}+\beta_{1} x_{1 i}+\cdots+\beta_{p} x_{p i}\right)}{1+\exp \left(\beta_{0}+\beta_{1} x_{1 i}+\cdots+\beta_{p} x_{p i}\right)}
$$

Untuk mempermudah estimasi parameter, maka persamaan logistik biner dituliskan sebagai berikut:

$$
\ln \left(\frac{\pi(x)}{1-\pi(x)}\right)=\beta_{0}+\beta_{1} x_{1 i}+\cdots+\beta_{p} x_{p i}
$$

2) Pengujian asumsi heteroskedastisitas

Uji asumsi heteroskedastisitas diuji menggunakan statistik uji Breusch-Pagan. Hipotesis yang digunakan adalah sebagai berikut:

$\mathrm{H}_{0}: \sigma_{1}^{2}=\sigma_{2}^{2}=\cdots=\sigma_{\mathrm{n}}^{2}=\sigma^{2}$ (Homoskedastis)

$\mathrm{H}_{1}$ : minimal ada satu $\sigma_{\mathrm{k}}^{2} \neq \sigma^{2}, \mathrm{k}=1,2, \ldots, \mathrm{n}$ (Heteroskedastis)

$$
\mathrm{BP}=\frac{1}{2} \mathrm{f}^{\mathrm{T}} \mathrm{Z}\left(\mathrm{Z}^{\mathrm{T}} \mathrm{Z}\right)^{-1} \mathrm{Z}^{\mathrm{T}} \mathrm{f}
$$

Keputusan akan tolak $\mathrm{H}_{0}$ apabila $\mathrm{BP}>\chi_{(\alpha ; \mathrm{k})}^{2}$.

3) Pengujian keberadaan aspek spasial

a) Autokorelasi spasial global

Pengukuran autokorelasi spasial, salah satunya dapat menggunakan Indeks

Moran atau yang biasa disebut Moran's $I$.

$\mathrm{H}_{0}: \mathrm{I}=0$ (Tidak terdapat autokorelasi antar lokasi)

$\mathrm{H}_{1}: \mathrm{I} \neq 0$ (Terdapat autokorelasi antar lokasi)

$$
\begin{gathered}
I=\frac{\mathrm{n}}{\sum_{\mathrm{i}=1}^{\mathrm{n}} \sum_{\mathrm{j}=1}^{\mathrm{n}} \mathrm{w}_{\mathrm{ij}}} \frac{\sum_{\mathrm{i}=1}^{\mathrm{n}} \sum_{\mathrm{j}=1}^{\mathrm{n}} \mathrm{w}_{\mathrm{ij}}\left(\mathrm{x}_{\mathrm{i}}-\overline{\mathrm{x}}\right)\left(\mathrm{x}_{\mathrm{j}}-\overline{\mathrm{x}}\right)}{\sum_{\mathrm{i}=1}^{\mathrm{n}}\left(\mathrm{x}_{\mathrm{i}}-\overline{\mathrm{x}}\right)^{2}} \\
\mathrm{Z}_{\text {hitung }}=\frac{\mathrm{I}-\mathrm{I}_{\mathrm{o}}}{\sqrt{\operatorname{var}(\mathrm{I})}}
\end{gathered}
$$

Keputusan akan tolak $\mathrm{H}_{0}$ apabila $\left|\mathrm{Z}_{\text {hitung }}\right|>\mathrm{Z}_{\alpha / 2}$. Nilai dari indeks I berkisar antara -1 hingga 1 . Apabila $\mathrm{I}>\mathrm{I}_{0}$ maka data memiliki autokorelasi spasial positif sedangkan apabila $\mathrm{I}<\mathrm{I}_{0}$ maka data memiliki autokorelasi spasial negatif.

b) Autokorelasi spasial lokal

Model untuk mengukur hubungan spasial untuk setiap lokasi individu (autokorelasi spasial lokal) berdasarkan pada statistik LISA (Local Indicators of Spatial Autocorrelation). Statistik LISA digunakan untuk menguji hipotesis dari distribusi acak dengan membandingkan nilai dari setiap observasi individu pada lokasi tertentu dengan nilai yang ada di tetangganya. Dalam model ini, akan diketahui kabupaten/kota mana saja yang memiliki angka IPM dan prevalensi perkawinan dini yang tinggi dan dikelilingi oleh kab/kota dengan angka yang tinggi pula, serta kabupaten/kota mana saja yang memiliki angka IPM dan 


\section{Jurnal Matematika, Statistika \& Komputasi \\ Afifah Jahra, Fiqih Tri Mahendra, Lathifah Dzakiyah, Salsavira}

prevalensi perkawinan dini yang rendah dan dikelilingi oleh kabupaten/kota dengan angka yang rendah pula. Selain itu dapat diketahui kabupaten/kota dengan angka IPM (Indeks Pembangunan Manusia) dan prevalensi perkawinan dini yang tinggi tetapi dikelilingi oleh kabupaten/kota dengan angka yang rendah dan sebaliknya.

4) Penetuan matriks pembobot

Dalam pembentukan penimbang digunakan fungsi kernel adaptive gaussian dan adaptive bisquare. Dari kedua metode ini akan dipilih jenis penimbang mana yang menghasilkan bandwidth optimum. Pemilihan matriks penimbang yang menghasilkan bandwidth optimum didasarkan pada nilai AIC (Aikake Information Criterion) dan percent deviance explained. Semakin kecil nilai AIC dan semakin besar percent deviance explained, maka semakin baik penimbang yang dihasilkan.

5) Estimasi parameter GWLR

Estimasi parameter pada model GWLR dapat dilakukan dengan metode Maximum Likelihood Estimation (MLE). Fungsi ln likelihood kemudian diberi pembobot spasial sehingga akan menghasilkan persamaan sebagai berikut [14]:

$$
\begin{aligned}
\ln L^{*}\left(\beta_{k}\left(u_{i}, v_{i}\right)\right)= & \sum_{k=0}^{p}\left(\sum_{j=1}^{n} w_{j}\left(u_{i}, v_{i}\right) y_{j} x_{j k}\right) \beta_{k}\left(u_{i}, v_{j}\right)-\sum_{j=1}^{n} w_{j}\left(u_{i}, v_{i}\right) \\
& \ln \left\{1+\exp \left(\sum_{k=0}^{p} \beta_{k}\left(u_{i}, v_{i}\right) x_{j k}\right)\right\}
\end{aligned}
$$

Persamaan log-likelihood tersebut tidak linier dalam parameternya, sehingga penyelesaian dari persamaan tersebut dapat diperoleh dengan metode iterasi numerik.

6) Pengujian signifikansi parameter GWLR

Pengujian secara parsial dilakukan untuk mengetahui apakah suatu variabel berpengaruh signifikan terhadap variabel dependen pada tiap-tiap lokasi [14].

$\mathrm{H}_{0}: \beta_{\mathrm{k}}\left(\mathrm{u}_{\mathrm{i}}, \mathrm{v}_{\mathrm{i}}\right)=0$

$\mathrm{H}_{1}: \beta_{\mathrm{k}}\left(\mathrm{u}_{\mathrm{i}}, \mathrm{v}_{\mathrm{i}}\right) \neq 0, \mathrm{k}=1,2,3, \ldots, \mathrm{p}$

$$
\mathrm{W}=\frac{\widehat{\beta_{\mathrm{k}}}\left(\mathrm{u}_{\mathrm{i}}, \mathrm{v}_{\mathrm{i}}\right)}{\operatorname{SE}\left(\widehat{\beta_{\mathrm{k}}}\left(\mathrm{u}_{\mathrm{i}}, \mathrm{v}_{\mathrm{i}}\right)\right)}
$$

Keputusan akan tolak $\mathrm{H}_{0}$ apabila $\left|\mathrm{W}_{\text {hitung }}\right|>\mathrm{Z}_{(\alpha / 2 ; \mathrm{p})}$.

7) Evaluasi model

Evaluasi model GWLR dilakukan dengan membandingkan nilai AIC dan percent deviance explained model GWLR dengan model regresi logistik. Model terbaik adalah model dengan AIC terkecil dan percent deviance explained terbesar.

\section{HASIL DAN PEMBAHASAN}

\subsection{Gambaran Umum IPM di Indonesia Tahun 2020}

Indeks Pembangunan Manusia (IPM) menggambarkan capaian pembangunan kualitas masyarakat di suatu daerah. Indeks ini disusun berdasarkan tiga dimensi dasar, yakni umur panjang dan hidup sehat, pengetahuan, dan standar hidup layak. Gambar di bawah ini merupakan visualisasi peta dari Indeks Pembangunan Manusia di Indonesia pada tahun 2020. Pengelompokan pada peta mengikuti klasifikasi IPM, dimana apabila IPM lebih dari atau sama dengan 80 (kategori sangat tinggi) maka ditandai dengan warna biru tua, IPM lebih dari atau 


\section{Jurnal Matematika, Statistika \& Komputasi \\ Afifah Jahra, Fiqih Tri Mahendra, Lathifah Dzakiyah, Salsavira}

sama dengan 70 hingga kurang dari 80 (kategori tinggi) ditandai dengan warna biru, IPM lebih dari atau sama dengan 60 hingga kurang dari 70 (kategori sedang) ditandai dengan warna biru muda, sedangkan IPM kurang dari 60 (kategori rendah) ditandai dengan warna putih.

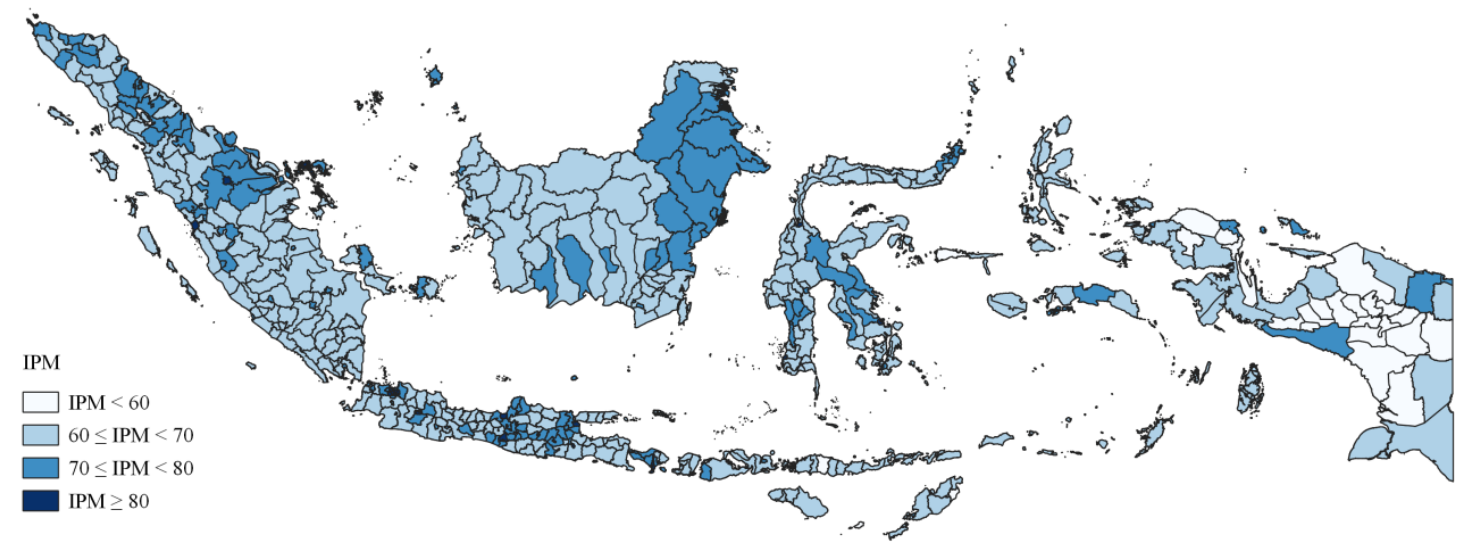

Gambar 3.1. Peta Sebaran IPM di Indonesia Tahun 2020

Berdasarkan peta tematik di atas dapat terlihat bahwa Indonesia bagian barat dan tengah didominasi oleh warna biru muda dan biru tua. Hal ini menandakan bahwa Indeks Pembangunan Manusia di wilayah tersebut sudah dalam tingkat sedang dan tinggi. Kondisi ini berbeda dengan Indonesia bagian timur, dimana berdasarkan gambar di atas, wilayah tersebut didominasi oleh warna biru muda dan putih. Warna tersebut menunjukkan bahwa Indeks Pembangunan Manusia di wilayah Indonesia timur masih dalam kategori sedang bahkan rendah.

\subsection{Gambaran Umum Prevalensi Perkawinan Dini di Indonesia Tahun 2020}

Pada penelitian ini data yang digunakan berupa prevalensi perkawinan dini di setiap kabupaten/kota di Indonesia. Visualisasi prevalensi perkawinan dini secara lebih lengkap dapat dilihat melalui peta tematik berikut, dimana warna biru tua menunjukkan prevalensi perkawinan dini yang tinggi, biru muda menunjukkan prevalensi perkawinan dini yang sedang, dan putih menunjukkan prevalensi perkawinan dini yang rendah.

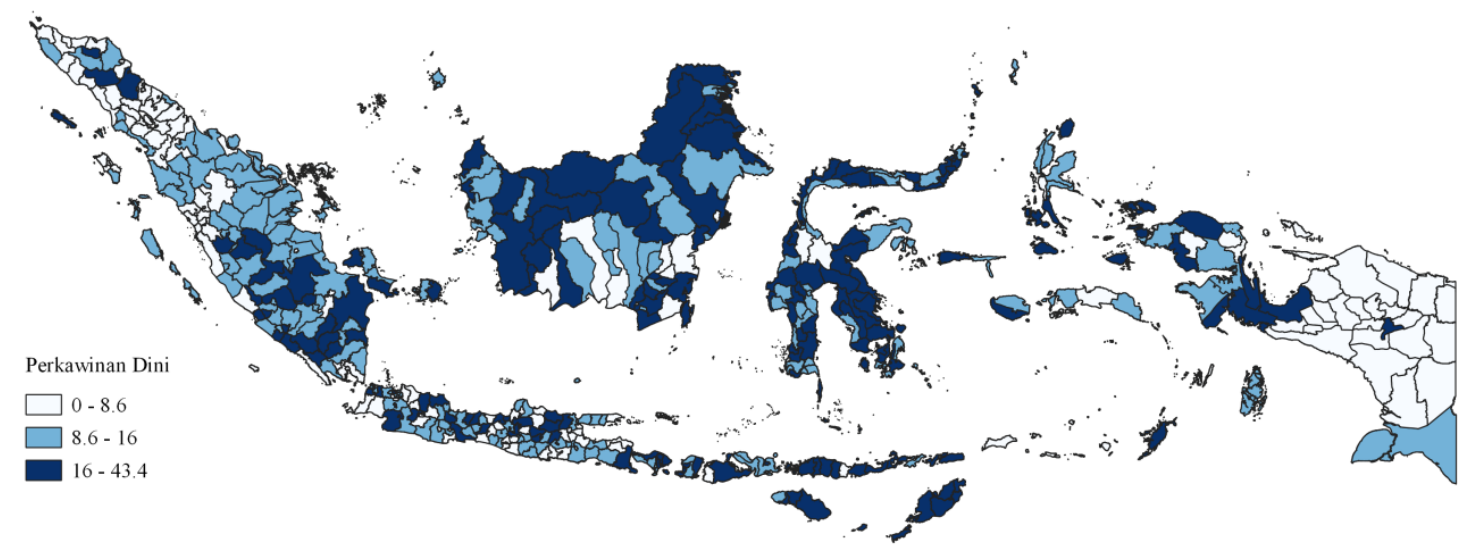

Gambar 3.2. Peta Sebaran Prevalensi Perkaiwnan Dini di Indonesia Tahun 2020

Berdasarkan peta di atas dapat dilihat bahwa kabupaten/kota yang memiliki prevalensi perkawinan dini yang tinggi hampir secara merata tersebar di seluruh Indonesia. Hal ini ditunjukkan dengan warna biru tua pada peta yang terdapat di setiap pulau-pulau besar di Indonesia. Akan tetapi, kondisi yang cukup berbeda ditunjukkan pada wilayah Indonesia bagian timur terutama di daerah Papua, dimana sebagian besar kabupaten/kota di daerah tersebut memiliki prevalensi perkawinan dini yang rendah. 


\section{Jurnal Matematika, Statistika \& Komputasi \\ Afifah Jahra, Fiqih Tri Mahendra, Lathifah Dzakiyah, Salsavira}

\subsection{Pengujian Asumsi Heteroskedastisitas}

Uji asumsi heteroskedastisitas dilakukan untuk melihat adanya kesamaan varians dari residual untuk seluruh pengamatan. Pengujian asumsi heteroskedastisitas dilakukan dengan uji Breusch-Pagan. Hasil pengujian menunjukkan nilai p-value sebesar 0,0000 yang kurang dari alpha $(0,05)$, sehingga dapat disimpulkan bahwa asumsi heteroskedastisitas terpenuhi.

\subsection{Autokorelasi Spasial}

Adanya autokorelasi spasial diuji dengan Global Moran's Index dan Local Indicator of Spatial Association (LISA). Untuk melihat signifikansi pada statistik uji Global Moran's Index, dapat dilakukan dengan randomization sebanyak 999 permutasi. Adapun hasil pengujiannya ditampilkan pada tabel berikut.

Tabel 3.1. Pengujian Autokorelasi Spasial Global

\begin{tabular}{clccc}
\hline Matriks Pembobot & \multicolumn{1}{c}{ Variabel } & Moran's I & Z-value & $\begin{array}{c}\text { Pseudo } P \text { - } \\
\text { value }\end{array}$ \\
\hline$(1)$ & \multicolumn{1}{c}{$(2)$} & $(3)$ & $(4)$ & $(5)$ \\
\hline $\begin{array}{l}\text { Inverse distance 9- } \\
\text { nearest neighbor }\end{array}$ & $\begin{array}{l}\text { IPM } \\
\text { Prevalensi } \\
\text { Perkawinan Dini }\end{array}$ & 0,295 & 15,7919 & 0,0010 \\
\hline
\end{tabular}

Diketahui bahwa pseudo p-value dari variabel IPM dan prevalensi perkawinan dini adalah sebesar 0,0010. Nilai tersebut kurang dari alpha yang digunakan, yakni sebesar 0,05, sehingga dapat disimpulkan bahwa kedua variabel memiliki autokorelasi spasial. Terdapatnya heteroskedastisitas dan dependensi spasial antar wilayah menyebabkan Geographically Weighted Logistic Regression (GWLR) tepat untuk digunakan.

Secara lebih rinci, keterkaitan spasial dapat dijelaskan melalui LISA (Local Indicators of Spatial Autocorrelation). LISA cluster map menunjukkan kabupaten/kota yang secara signifikan memiliki autokorelasi spasial.

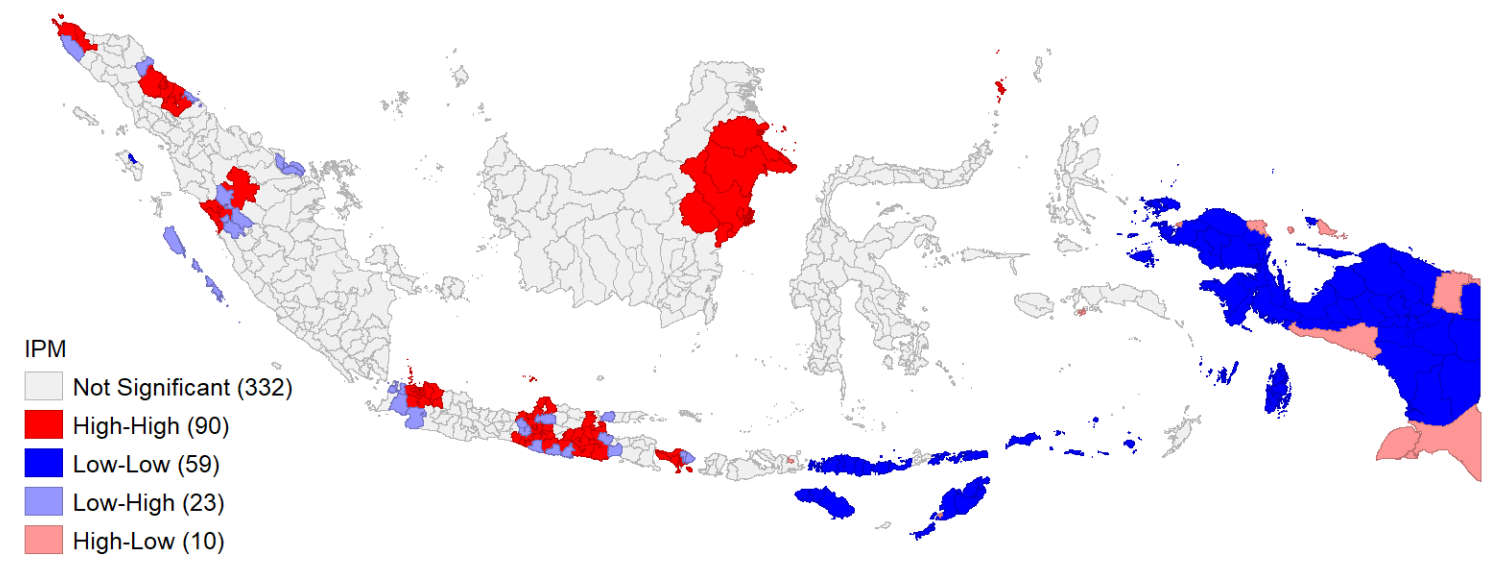

Gambar 3.3. LISA Cluster Map Variabel IPM

Pengelompokkan IPM dengan kategori high-high terletak pada beberapa kabupaten/kota di Provinsi Aceh, Sumatera Utara, Sumatera Barat, DKI Jakarta, Banten, Jawa Barat, Jawa Tengah, Jawa Timur, Bali, dan Kalimantan Timur, sedangkan pengelompokkan IPM dengan kategori lowlow terutama terletak di Provinsi Nusa Tenggara Timur, Maluku, Papua Barat, dan Papua. 


\section{Jurnal Matematika, Statistika \& Komputasi}

\section{Afifah Jahra, Fiqih Tri Mahendra, Lathifah Dzakiyah, Salsavira}

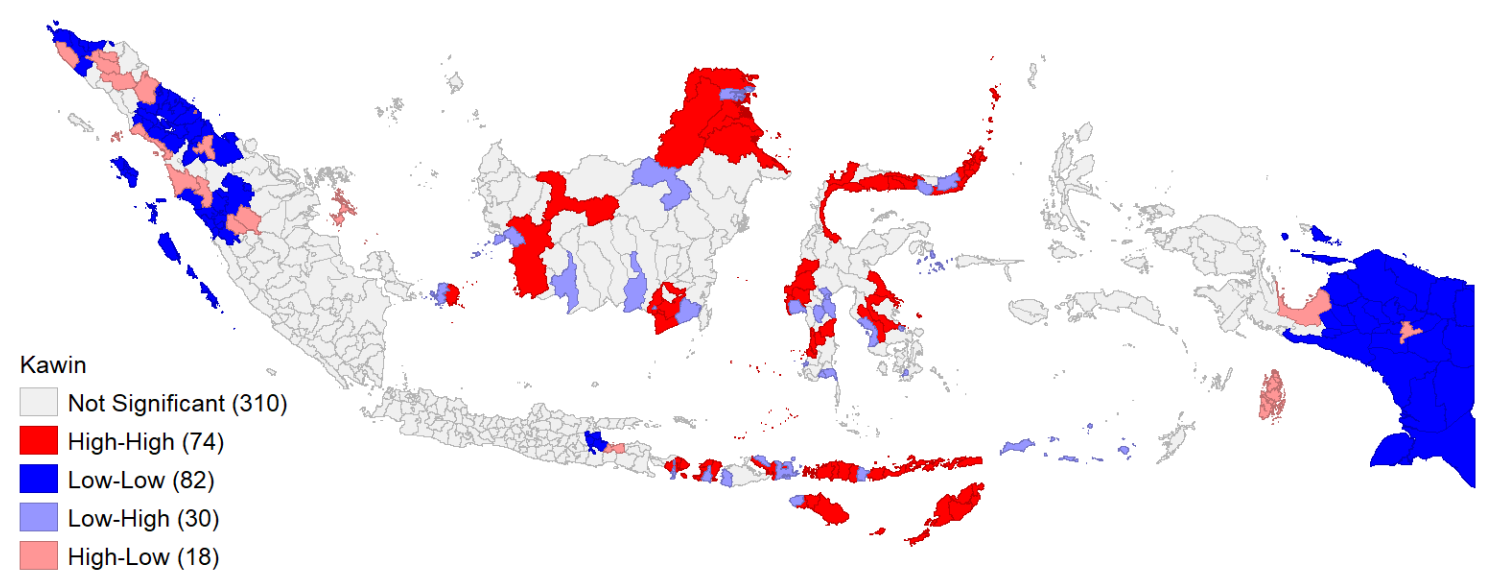

Gambar 3.4. LISA Cluster Map Variabel Prevalensi Perkawinan Dini

Pengelompokkan prevalensi perkawinan dini dengan kategori high-high terletak pada beberapa kabupaten/kota di Provinsi Kalimantan Utara, Kalimantan Barat, Kalimantan Selatan, Sulawesi Utara, Gorontalo, Sulawesi Tengah, Sulawesi Barat, Sulawesi Tengah, Sulawesi Tenggara, Sulawesi Selatan, Bali, NTT, dan NTB, sedangkan pengelompokkan prevalensi perkawinan dini dengan kategori low-low terutama terletak di Provinsi Aceh, Sumatera Utara, Sumatera Barat, dan Papua.

\subsection{Penentuan Matriks Pembobot}

Langkah awal yang harus dilakukan dalam pemodelan GWLR adalah menentukan penimbang spasial untuk setiap kabupaten/kota. Pada penelitian ini, penimbang yang digunakan adalah adaptive bisquare. Penimbang ini digunakan karena kerapatan dan jarak antar pusat wilayah yang bervariasi. Adaptive bandwith akan menerapkan bandwidth yang kecil pada lokasi yang rapat dan bandwidth yang besar pada lokasi yang distribusi wilayahnya jarang. Lebih lanjut, adaptive bisquare menghasilkan nilai AIC yang lebih kecil dibandingkan adaptive gaussian, nilai percent deviance explained pada penimbang adaptive bisquare juga lebih besar dibandingkan adaptive gaussian, sehingga penimbang adaptive bisquare lebih baik untuk digunakan. Pada penimbang adaptive bisquare didapatkan bandwidth optimum sebesar 57. Hal ini menunjukkan bahwa terdapat 57 kabupaten/kota tetangga terdekat yang berpengaruh signifikan terhadap nilai estimasi di suatu kabupaten/kota.

Tabel 1.2. Perbandingan Matriks Pembobot

\begin{tabular}{cccc}
\hline Model & $\begin{array}{c}\text { Bandwidth } \\
\text { Optimum }\end{array}$ & AIC & $\begin{array}{c}\text { Percent Deviance } \\
\text { Explained }\end{array}$ \\
\hline$(1)$ & $(2)$ & $(3)$ & $(5)$ \\
\hline Adaptive Bisquare & 57 & 594,49 & 0,28 \\
Adaptive Gaussian & 54 & 627,36 & 0,15 \\
\hline
\end{tabular}

\subsection{Estimasi Parameter dan Pengujian Signifikansi Parameter GWLR}

Pembentukan model lokal dilakukan dengan mengidentifikasi kabupaten/kota apa saja yang signifikan dalam pengaruh prevalensi perkawinan dini terhadap IPM. Dengan tingkat kepercayaan sebesar 95 persen, pengaruh prevalensi perkawinan dini terhadap IPM ditemukan signifikan di 172 kabupaten/kota yang tersebar di seluruh Indonesia. Secara lebih jelas, hal tersebut ditampilkan melalui visualisasi peta berikut. 


\section{Jumal Matematika, Statistika \& Komputasi \\ Afifah Jahra, Fiqih Tri Mahendra, Lathifah Dzakiyah, Salsavira}

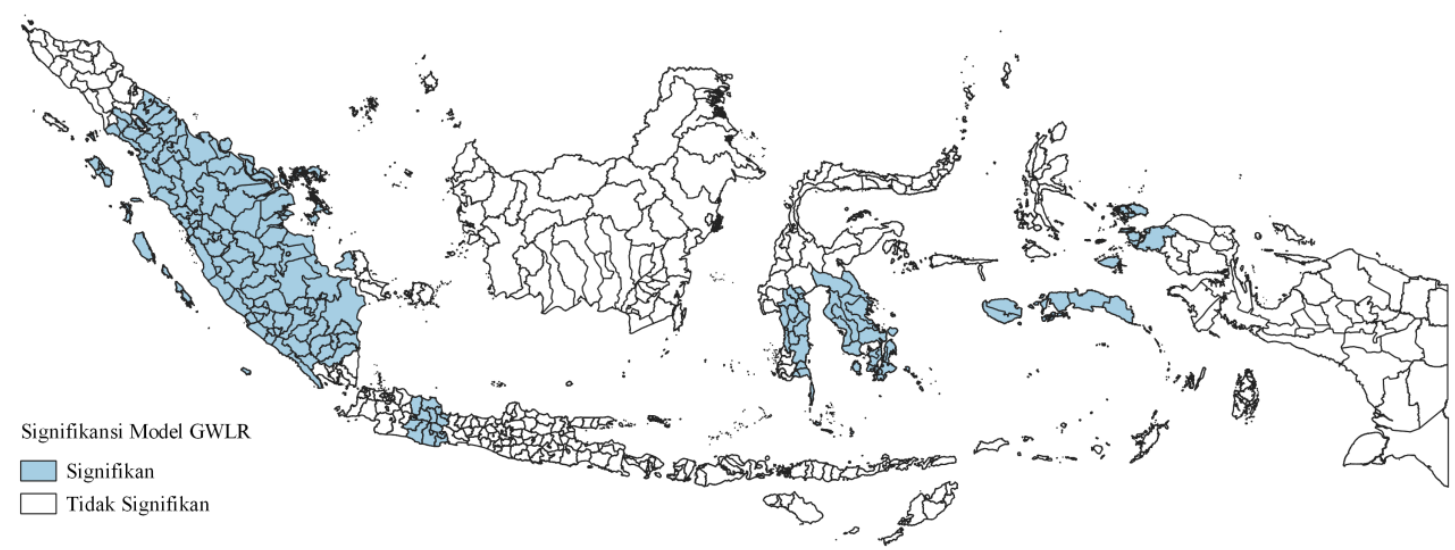

Gambar 3.5. Peta Signifikansi Model GWLR

Pengaruh yang signifikan antara prevalensi perkawinan dini terhadap IPM terdapat di beberapa kabupaten/kota yang berada di Provinsi Aceh, Sumatera Utara, Sumatera Barat, Riau, Jambi, Sumatera Selatan, Bengkulu, Lampung, Kepulauan Bangka Belitung, Kepulauan Riau, Jawa Barat, Sulawesi Tengah, Sulawesi Selatan, Sulawesi Tenggara, Maluku, dan Papua Barat. Seluruh koefisien variabel prevalensi perkawinan dini pada kabupaten/kota yang memiliki pengaruh signifikan bernilai negatif. Tanda koefisien yang negatif menunjukkan bahwa prevalensi perkawinan dini memiliki pengaruh negatif terhadap IPM.

Adapun untuk melihat besar pengaruh variabel prevalensi perkawinan dini terhadap IPM, dapat dihitung dengan mengeksponensialkan koefisien model GWLR. Besar pengaruh pada kabupaten/kota yang menunjukkan pengaruh signifikan berkisar antara 0,5688 hingga 0,8953.

Tabel 3.3. Estimasi Koefisien Model GWLR Pada Kabupaten/Kota yang Menunjukkan Pengaruh Signifikan

\begin{tabular}{ccc}
\hline Kabupaten/Kota & Provinsi & $\begin{array}{c}\text { Estimasi Koefisien } \\
\text { Prevalensi Perkawinan Dini }\end{array}$ \\
\hline$(1)$ & $(2)$ & $(3)$ \\
\hline Kabupaten Mandailing Natal & Sumatera Utara & 0,6689 \\
Kabupaten Siak & Riau & 0,7202 \\
Kabupaten Konawe Kepulauan & Sulawesi Tenggara & 0,8710 \\
\hline
\end{tabular}

Tabel di atas menunjukkan tiga kabupaten/kota (dipilih secara acak) yang memiliki prevalensi perkawinan dini yang berpengaruh negatif terhadap IPM. Dari tabel tersebut dapat diketahui bahwa penambahan prevalensi perkawinan dini sebesar satu satuan di Kabupaten Mandailing Natal dapat menurunkan kecenderungan IPM di kabupaten tersebut sebesar 0,6689, dengan kata lain kecenderungan Kabupaten Mandailing Natal untuk setiap peningkatan prevalensi perkawinan dini sebesar satu satuan adalah sebesar 0,6689 kali untuk memiliki IPM yang rendah.

Hubungan yang signifikan dan negatif antara variabel prevalensi perkawinan dini terhadap IPM di beberapa kabupaten/kota di Indonesia disebabkan oleh dampak buruk dari perkawinan dini. Pengaruh tersebut tercermin dalam dimensi-dimensi yang terdapat di dalam IPM. Child Marriage Report 2020 dalam publikasinya telah menjelaskan keterkaitan hal tersebut [2]. Pada dimensi umur panjang dan hidup sehat, perkawinan dini dapat meningkatkan peluang kehamilan beresiko tinggi, sehingga dapat menyebabkan kematian ibu maupun bayi. Perempuan berusia 1014 tahun memiliki kemungkinan kematian lima kali lebih besar dibandingkan dengan perempuan berusia 20-25 tahun, dan secara global kematian yang disebabkan oleh kehamilan merupakan penyebab utama kematian anak perempuan usia 15-19 tahun [4]. Pada dimensi pengetahuan, perkawinan dini dapat mengakibatkan terjadinya tingkat putus sekolah yang tinggi [3]. Dan faktanya di Indonesia, hanya 5,6\% remaja dengan pernikahan dini yang masih melanjutkan 


\section{Jurnal Matematika, Statistika \& Komputasi \\ Afifah Jahra, Fiqih Tri Mahendra, Lathifah Dzakiyah, Salsavira}

sekolah setelah kawin [7]. Pada dimensi standar hidup layak, perkawinan dini dapat menyebabkan meningkatnya kemiskinan. Susenas Maret 2018 menunjukkan, perempuan usia 2024 tahun yang kawin pada usia sebelum 18 tahun yang berstatus miskin lebih besar dibandingkan yang kawin di atas usia 18 tahun, yaitu 13,76 persen berbanding 10,09 persen [2].

\subsection{Evaluasi Model GWLR}

Untuk mengetahui model mana yang merupakan model terbaik, dapat dilakukan dengan membandingkan AIC dan percent deviance explained dari masing-masing model.

Tabel 3.4. Evaluasi Model

\begin{tabular}{ccc}
\hline Model & AIC & $\begin{array}{c}\text { Percent Deviance } \\
\text { Explained }\end{array}$ \\
\hline$(1)$ & $(2)$ & $(3)$ \\
\hline Regresi Logistik & 682,65 & 0,04 \\
GWLR & 594,49 & 0,28 \\
\hline
\end{tabular}

Model GWLR menghasilkan nilai AIC yang lebih kecil dan percent deviance explained yang lebih besar dibandingkan model regresi logistik, sehingga dapat dikatakan model GWLR lebih baik digunakan untuk memodelkan prevalensi perkawinan dini terhadap IPM dibandingkan model regresi logistik.

\section{KESIMPULAN}

Berdasarkan hasil dan pembahasan penelitian, maka dapat diambil kesimpulan sebagai berikut:

1. Indeks Pembangunan Manusia di wilayah Indonesia bagian barat dan tengah sudah berada dalam tingkat sedang dan tinggi, sedangkan Indonesia bagian timur masih dalam kategori sedang bahkan rendah.

2. Prevalensi perkawinan dini yang tinggi tersebar secara merata di seluruh Indonesia.

3. Prevalensi perkawinan dini berpengaruh secara negatif dan signifikan di Provinsi Aceh, Sumatera Utara, Sumatera Barat, Riau, Jambi, Sumatera Selatan, Bengkulu, Lampung, Kepulauan Bangka Belitung, Kepulauan Riau, Jawa Barat, Sulawesi Tengah, Sulawesi Selatan, Sulawesi Tenggara, Maluku, dan Papua Barat.

4. Pemodelan prevalensi perkawinan dini terhadap Indeks Pembangunan Manusia lebih baik dilakukan dengan menggunakan Geographically Weighted Logistic Regression dibandingkan dengan model regresi logistik.

\section{DAFTAR PUSTAKA}

[1] Badan Kependudukan dan Keluarga Berencana Nasional (BKKBN), 2012. Pernikahan Dini pada Beberapa Provinsi di Indonesia: Akar Masalah dan Peran Kelembagaan di Daerah. Direktorat Analisis Dampak Kependudukan BKKBN, Jakarta.

[2] Badan Pusat Statistik, 2020. Pencegahan Perkawinan Anak Percepatan yang Tidak Bisa Ditunda. BPS, Jakarta.

[3] Birchall, J., 2018. Early Marriage, Pregnancy and Girl Child School Dropout.

[4] BPS \& UNICEF, 2016. Kemajuan yang Tertunda: Analisis Data Perkawinan Usia Anak di Indonesia. BPS, Jakarta.

[5] International Center for Research on Women (ICRW), 2003. Too Young to Wed: The Lives, Rights, and Health of Young Married Girls. ICRW, Washington DC. 


\section{Jurnal Matematika, Statistika \& Komputasi \\ Afifah Jahra, Fiqih Tri Mahendra, Lathifah Dzakiyah, Salsavira}

[6] Kementerian Pemberdayaan Perempuan dan Perlindungan Anak Republik Indonesia (Kementerian PPA), 16 Februari 2021. Mengancam Masa Depan, Mari Cegah Perkawinan Anak, Siaran Pers Nomor: B- 027/SETMEN/ HM.02.04/02/2021. https://www.kemenpppa.go.id/index.php/page/read/29/3053/mengancam-masa-depan-maricegah-perkawinan-anak

[7] Kumaidi, \& Amperaningsih, Y., 2015. Hubungan Sikap dan Status Ekonomi dengan Pernikahan Dini pada Remaja Putri. Jurnal Ilmiah Keperawatan Sai Betik, Vol. 11, No. 1, 75-80.

[8] Suara.com., 21 Oktober 2020. Kasus Pernikahan Dini Meningkat Selama Masa Pandemi. https://yoursay.suara.com/news/2020/10/21/110151/kasuspernikahan-dini-meningkatselamamasa-pandemi

[9] UNICEF Indonesia, BPS, PUSKAPA UI, \& Kementerian PPN/Bappenas, 2020. Perkawinan Anak Fact Sheet. https://unicef.org/indonesia/id/laporan/perkawinananak-diindonesia

[10] United Nations (UN), 2015. Sustainable Development Goals. (n.d.). Goals 5: Achieve Gender Equality and Empower All Women and Girls. http://sustainabledevelopment.un.org/sdg5

[11] United Nations Children's Fund (UNICEF), 2008. Early Marriage: Child Spouses. Innocenti Digest, No. 7.

[12] United Nations Children's Fund (UNICEF), 2020. A Generation to Protect: Monitoring violence, exploitation and abuse of children within the SDG framework. UNICEF, New York.

[13] United Nations Programme on HIV and AIDS (UNAIDS), 2017. Supporting Efforts to End Child Marriage in Latin America and The Caribbean. http://www.unaids.org/en/resources/presscentre/featurestories/2017/march/20170324_endchild-marriage

[14] Widyastuti, L., Yuniarti, D., \& Hayati, M. N., 2018. Pemodelan Faktor-Faktor yang Berpengaruh Terhadap Indeks Pembangunan Manusia (IPM) di Kalimantan dengan Geographically Weighted Logistic Regression (GWLR). Jurnal Eksponensial, Vol. 9, No. 1, 67-74. 